\title{
MAPK10 wt Allele
}

National Cancer Institute

\section{Source}

National Cancer Institute. MAPK10 wt Allele. NCI Thesaurus. Code C51215.

Human MAPK10 wild-type allele is located within 4q22.1-q23 and is approximately $344 \mathrm{~kb}$ in length. This allele, which encodes mitogen-activated protein kinase 10 protein, is involved in the regulation of both apoptosis and growth cone microtubule formation in neurons exposed to cellular stresses. 